Estuarine, Coastal and Shelf Science

December 2016, Volume 182, Part B, Pages 235-242

http://dx.doi.org/10.1016/j.ecss.2016.06.014

http://archimer.ifremer.fr/doc/00343/45410/

(c) 2016 Elsevier Ltd. All rights reserved.

\title{
Effect of electrolysis treatment on the biomineralization capacities of pearl oyster Pinctada margaritifera juveniles
}

\author{
Latchere Oihana ${ }^{1}$, Fievet Julie ${ }^{1}$, Lo Cedrik ${ }^{2}$, Schneider Denis ${ }^{3}$, Dieu Stéphanie ${ }^{3}$, Cabral Philippe ${ }^{4}$, \\ Belliard Corinne ${ }^{1}$, Ky Chin-Long ${ }^{1}$, Gueguen Yannick ${ }^{1,5}$, Saulnier Denis ${ }^{1, *}$
}

${ }^{1}$ Ifremer, UMR 241 EIO, UPF-ILM-IRD, Labex Corail, B.P. 7004, 98719 Taravao, Tahiti, French

Polynesia

${ }^{2}$ Direction des Ressources Marines et Minières, Tahiti, French Polynesia

${ }^{3}$ Espace Bleu, Bora-Bora, French Polynesia

${ }^{4}$ Gauguin's Pearl Farm, Rangiroa, French Polynesia

${ }^{5}$ Ifremer, UMR 5244 IPHE, UPVD, CNRS, Université de Montpellier, CC 80, F-34095 Montpellier,

France

*Corresponding author : Denis Saulnier, email address : denis.saulnier@ifremer.fr

\begin{abstract}
:
The present study investigated the effect of electrolysis on the biomineralization capacities of juveniles of the mollusk Pinctada margaritifera for the first time. Size-selected individuals from two groups, "Medium" and "Large", from a multi-parental family produced in a hatchery system were subjected to electrolysis under a low voltage current over a nine-week experimental period. The growth of the juveniles was individually monitored and assessed weekly by wet weight and shell height measurements. At the end of the experiment, mantle tissue was sampled for biomineralization-related gene expression analysis. Electrolysis significantly increased pearl oyster growth in terms of shell height and wet weight for Large juveniles from the 5th and the 2nd week, respectively, until the end of the experiment. However, differences were only significant for Medium individuals from the 7th week for shell height and from the 9th week for wet weight. Furthermore, transcriptional analysis of six known biomineralization genes coding for shell matrix proteins of calcitic prisms and/or nacreous shell structures revealed that five were significantly overexpressed in the mantle mineralizing tissue under electrolysis: three in common between the two size class groups and two that were expressed exclusively in one or the other group. Finally, we found no statistical difference of the shell thickness ratio between individuals undergoing electrolysis and control conditions. Taken together, our results indicate, for the first time in a calcifying marine organism, that electrolysis influences molecular mechanisms involved in biomineralization and may stimulate some parameters of pearl oyster growth rate.
\end{abstract}




\section{Graphical abstract}
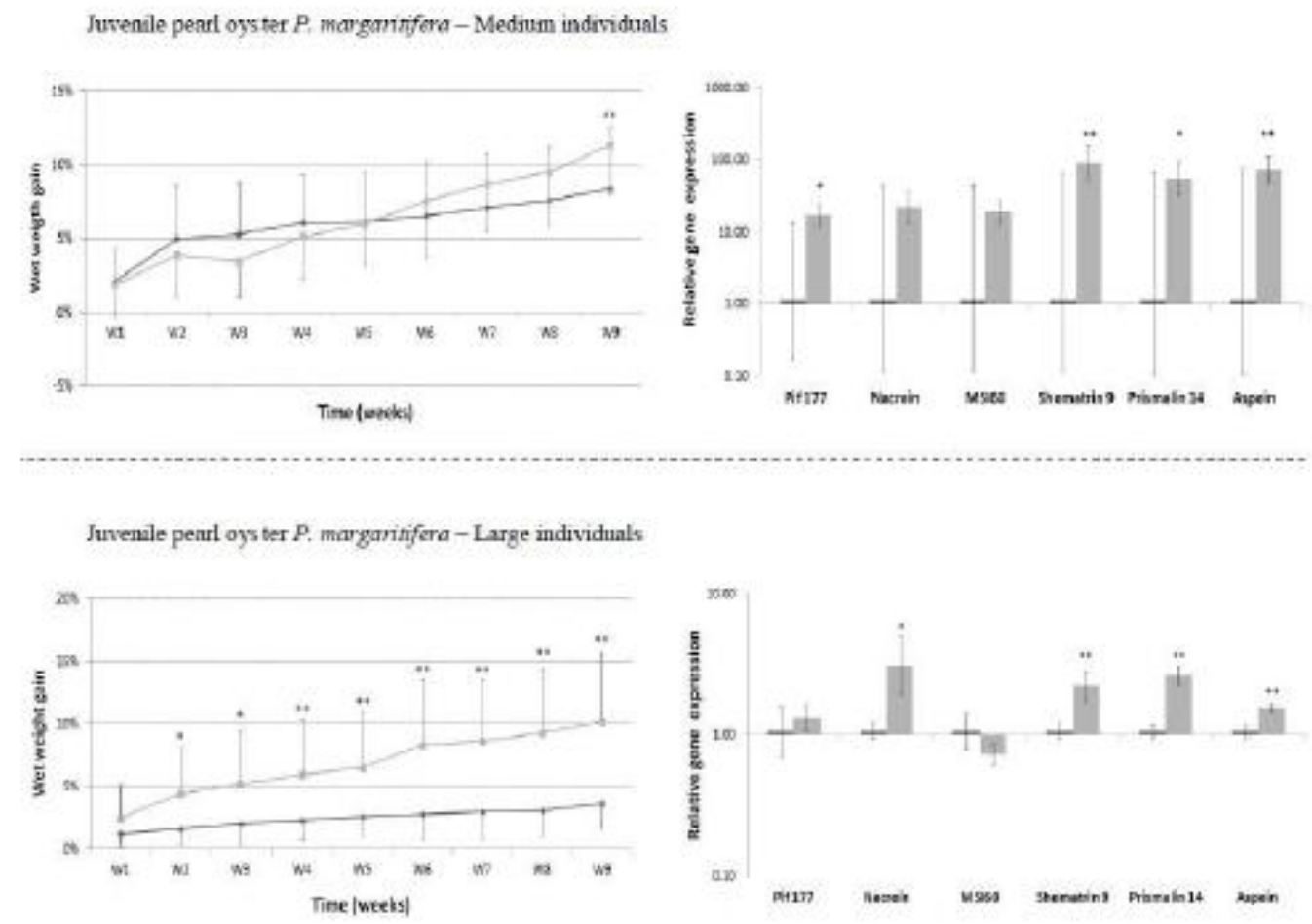

\section{Highlights}

Electrolysis may increase some growth rate parameters in juvenile pearl oysters. Expression levels of some biomineralization-related genes are enhanced by electrolysis. - No effect of electrolysis was recorded on shell thickness of juvenile pearl oysters.

Keywords : Pearl oyster, Pinctada margaritifera, Electrolysis, Biomineralization, Gene expression 


\section{Introduction ACCEPTED MANUSCRIPT}

The cultured pearl industry, with around US\$784 million worth of production in 2005 (Tisdell and Poirine, 2008), is of great economic importance for a number of countries in tropical and subtropical regions. In French Polynesia, the black-lip pearl oyster Pinctada margaritifera "Linnaeus 1758 " is the top aquaculture species and the basis of the mass production of a unique gem built by a living organism. Not only is pearl culture the second highest economic resource of French Polynesia (65 million Euros export value in 2013, customs statistics, Wane, 2013), but it also represents an important source of employment (nearly 5,000 people employed on 487 farms in 2013) (Ky et al., 2014). However, since the early 2000s, this industry has suffered a severe crisis, mainly due to overproduction and a slowdown of the world economy, leading to a dramatic fall in mean pearl value per gram. Pearl size and quality are among the most important factors that go into determining pearl value (Blay et al., 2014). Increasing cultured pearl quality, through cultural practices and/or genetic selection, is the biggest challenge for research and development.

Production of cultured pearls is achieved starting with a surgical operation called "grafting" carried out by skilled technicians. A small piece of mantle tissue is removed from a donor oyster to be inserted into the gonad of a recipient oyster, along with a spherical nucleus made of mollusk shell or synthetic material (Kishore and Southgate, 2014; Taylor and Strack, 2008; Cochennec-Laureau et al., 2010). P. margaritifera recipient oysters are used for graft operations when their shell height has reached $11 \mathrm{~cm}$, at approximately two years of age (Gervis and Sims, 1992). An additional 18- to 24-month period is required to produce a pearl with a sufficiently thick layer of nacre $(0.8 \mathrm{~mm})$ for harvest. In French Polynesia, $P$. margaritifera shell growth increments are highly variable, with higher growth rates in island lagoons and the open ocean compared with the atoll lagoons where they are usually reared (Pouvreau and Prasil, 2001). Improving pearl oyster growth and reducing the length of the culture time needed to reach a suitable size for graft operations would contribute significantly 
to increase the cost-effectiveness of the industry. Moreover, recipient pearl oyster shell increments are correlated with the pearl nacre deposition rate (Coeroli and Mizuno, 1985; Le Pabic et al., this issue). Thus, producing larger pearl oysters would potentially lead to the formation of thicker nacre layers.

P. margaritifera shell growth relies on the formation of a mineral phase composed of layers of calcium carbonate and an organic matrix containing mostly proteins, glycoproteins, lipids and polysaccharides (Joubert et al., 2010; Levi-Kalisman et al., 2001). This organic matrix, secreted by the epithelial cells of the external mantle, controls nucleation, orientation, growth, and the polymorphism of the calcium carbonate crystals formed as aragonite or calcite (Mann, 1988; Belcher et al., 1996). Shell matrix proteins play a major role in the shell biomineralization process. Some genes encoding matrix proteins have been identified and are known to be specifically involved in the formation of the nacreous layer and/or prismatic layer (Joubert el al., 2010; Montagnani et al., 2011; Marie et al., 2012). For example, the genes Pif177 and MSI60 are involved in shell nacreous layer formation by regulating aragonite crystal growth (Suzuki et al., 2009, Sudo et al. 1997). Shematrin proteins are secreted into the prismatic layer where they are thought to establish a structure for calcitic prism formation (Yano et al., 2006). Prismalin 14 controls calcitic prism calcification (Suzuki et al., 2004), and Aspein is thought to play a key role in calcite precipitation (Isowa et al., 2012). In contrast, some proteins such as Nacrein are involved in both the aragonite and calcite mineralization processes (Miyamoto et al., 2013).

The mineral accretion method, based on the electrolysis of seawater, involves a lowvoltage direct electrical current through two submerged electrodes to induce deposition of dissolved minerals on conductive substrates (Hilbertz, 1979). Seawater is split into hydrogen gas $\mathrm{H}_{2}$ and hydroxide ion $\mathrm{HO}^{-}$, leading to an increase of the $\mathrm{pH}$ in the vicinity of the cathode. Calcium ions $\mathrm{Ca}^{2+}$ from seawater combine with dissolved bicarbonate $\mathrm{HCO}_{3}{ }^{-}$to precipitate as 
aragonite $\mathrm{CaCO}_{3}$ and magnesium ions $\mathrm{Mg}^{+}$with hydroxide ions to precipitate as brucite $\mathrm{Mg}(\mathrm{OH})_{2}$. Several experiments have been conducted to study the effect of this mineral accretion method on survival and growth rate of marine calcifying organisms, such as corals and oysters (Borell et al., 2010; Piazza et al., 2009; Sabater and Yap, 2002, 2004; van Treeck and Schuhmacher, 1997). Results vary considerably, since some studies on the effect of the mineral accretion method report increased survival rate of coral transplants (van Treeck and Schuhmacher 1997; Sabater and Yap, 2002) and enhanced coral growth rate (Sabater and Yap, 2004) whereas other studies show lower growth rates for juvenile oysters (Piazza et al, 2009) and no effect or a negative effect on coral survival (Borell et al., 2010).

Surprisingly, studies on the effect of electrolysis on mollusk and coral biomineralization have only focused on biometric analysis of calcifying tissues. Indeed, to our knowledge, no molecular approaches have yet been explored to characterize biomineralization processes under electrolysis treatment. With the advent of proteomic, transcriptomic, and genomic technologies, several biomineralization-related proteins, referred to as the biomineralization "toolkit" have been recently identified in the pearl oyster P. margaritifera (Marie et al., 2012).

This study is the first aiming to investigate the effect of electrolysis on the biomineralization capacities of the black-lipped pearl oyster $P$. margaritifera. Some growth parameters (shell thickness, height, animal weight) and the expression level of six biomineralization-related genes were measured in juvenile $P$. margaritifera.

\section{Materials and Methods}

\subsection{Biological material}


A multi-parental family was produced in the Ifremer hatchery facilities in Vairao

131 (Tahiti, French Polynesia) using a cross between three female and six male broodstock oysters. Artificial spawning, larval rearing, and oyster culture were conducted as described in Ky et al. (2013). Juveniles were reared in the same natural environment, in Aquapurse® plastic trays suspended on long lines located in Vairao lagoon (Tahiti). At 180 days post fertilization, oysters were categorized into two groups according to their shell size: 40 "Medium" size (mean shell height of $3.8 \mathrm{~cm} \pm 0.4$ and mean wet weight of $5.64 \mathrm{~g} \pm 1.47$ ) and 30 "Large" size (mean shell height of $5.1 \mathrm{~cm} \pm 0.4$ and mean wet weight of $12.44 \mathrm{~g} \pm 3.42$ ). All pearl oyster juveniles were transferred by airplane from Vairao lagoon to Bora Bora lagoon (GPS location, 16.528553 S, 151.768184 E, French Polynesia).

\subsection{Experimental design}

Two conditions were tested for an experimental period of nine weeks in the lagoon of

Bora Bora using a total of 70 pearl oysters: electrolysis using low-voltage electric current and control conditions (no electrolysis). Twenty Medium and 15 Large juvenile pearl oysters were randomly selected and subjected to each condition. These pearl oysters were randomly hung on chaplets (ropes) in two Aquapurse ${ }^{\circledR}$ plastic trays to prevent predation from shellfish and fish (Fig. 1). Pearl oysters under electricity were placed on a steel structure subjected to a low-voltage current of $3.7 \mathrm{~V}$, flowing between the positively charged anode and the negatively charged cathode. The electrolysis structure was switched on every other hour from 4 AM to 7 PM alternating with periods of an hour with no current. This structure was used two months prior to the oyster experiment so that mineral accretion occurred at the cathode where calcium carbonate and magnesium hydroxide were deposited. Both electrically charged structures and the identical uncharged control structures were fixed to pillars at $3.5 \mathrm{~m}$ depth set 20 meters apart from one another. 
Tagged juvenile pearl oysters were individually measured weekly for shell height and live weight. For each individual, absolute cumulative shell growth and wet weight gain were calculated by the formula $\mathrm{PR}=\left(100 \mathrm{x}\left(\mathrm{V}_{\mathrm{W}}-\mathrm{V}_{\mathrm{W} 0}\right)\right) / \mathrm{V}_{\mathrm{W} 0}$, where $\mathrm{PR}$ is the percent change, $\mathrm{V}_{\mathrm{W}}$ the present value by week "W" and $\mathrm{V}_{\mathrm{w} 0}$ the initial value by week $\mathrm{W} 0$ when oysters were placed on the charged and uncharged (control) structures. After nine weeks of monitoring, all the pearl oyster juveniles were collected.

\subsection{Mantle gene expression}

For gene expression analysis, mantle tissue samples from four to five randomly chosen individuals were pooled for each of the tested conditions (electrolysis versus control), resulting in three and five pools per condition for Large and Medium oyster batches, respectively. Total cellular RNA was extracted using TRIZOL reagent (Life Technologies) according to the manufacturer's recommendations. RNA was quantified using a NanoDrop ND-1000 spectrophotometer (NanoDrop Technologies Inc.). For each sample, $3 \mu \mathrm{g}$ of total RNA was treated with DNase (Ambion) to degrade any potential DNA contaminants. The expression levels of six biomineralization-related genes were analyzed by quantitative RTPCR analysis using a set of forward and reverse primers (Table 1). Three other genes were used as housekeeping genes, including 18S rRNA (Larsen et al., 2005), REF1 (Joubert et al., 2014) and GAPDH (Lemer et al., 2015). First-strand cDNA was synthesized from $400 \mathrm{ng}$ of total RNA using a Transcriptor First Strand cDNA Synthesis Kit (Roche) and a combination of random hexamer and oligo(dT) primers, in a final reaction volume of $25 \mu 1$. Quantitative PCR (qPCR) amplifications were carried out on a Stratagene MX3000P, using Brilliant II SYBR Green QPCR Master Mix (Stratagene) with $400 \mathrm{nM}$ of each primer and $10 \mu \mathrm{L}$ of 1:100 diluted cDNA template. The PCR reactions consisted of a first step of $10 \mathrm{~min}$ at $95^{\circ} \mathrm{C}$ followed by 40 cycles $\left(95^{\circ} \mathrm{C}\right.$ for $30 \mathrm{~s}, 60^{\circ} \mathrm{C}$ for $30 \mathrm{~s}$ and $72^{\circ} \mathrm{C}$ for $\left.1 \mathrm{~min}\right)$. At the end, an 
additional cycle was performed from 55 to $95{ }^{\circ} \mathrm{C}$, increasing by $0.1{ }^{\circ} \mathrm{C}$ every second, to generate the dissociation curves and to verify the specificity of the PCR products. All measurements were performed on duplicate samples.

Expression levels were estimated by evaluating the fluorescence signal emitted by SYBR-Green ${ }^{\circledR}$. This fluorescent marker binds to double-stranded DNA (dsDNA) and the fluorescence emitted is proportional to the dsDNA present in the reaction mix. Calculations are based on cycle threshold $(\mathrm{Ct})$ values. The relative gene expression ratio of each biomineralization-related gene was calculated following the delta-delta method normalized with three reference genes (Livak and Schmittgen, 2001), which is defined as : ratio $=2^{-[\Delta \mathrm{Ct}}$ sample- $\Delta \mathrm{Ct}$ control] $=2^{-\Delta \Delta \mathrm{Ct}}$. In this formula, the $\Delta \mathrm{Ct}$ control represents the mean of the $\Delta \mathrm{Ct}$ values obtained for each target gene in control pearl oysters.

\subsection{Shell labeling and thickness ratio}

(1)

One day before shipment to Bora Bora Island, the seventy oysters were immersed for $12 \mathrm{~h}$ in a $150 \mathrm{mg} \mathrm{L}^{-1}$ calcein (Sigma Aldrich) solution prepared with $0.1-\mu \mathrm{m}$ filtered seawater. After the experimental period of nine weeks, shells were sawn along the dorso-ventral axis using a "SwapTop Trim Saw" machine (Inland, Middlesex, United Kingdom). Ventral sides of shell cross sections were observed by epifluorescence microscopy under a Leica DM400B UV microscope (I3 filter block and LAS V.8.0 software for size measurements). The shell thickness ratio was measured by dividing the thickness of the new nacre deposits formed during the nine-week experimental period by the total thickness of the shell cross section. A mean of two measurements was calculated for each cross section.

\subsection{Statistical analysis}


Normality of data distribution and homogeneity of variance were tested using the

Shapiro-Wilk test and Bartlett test, respectively. Data analysis was performed at 5\% alpha level using XLSTAT (version 1.01, 2014). As the assumptions for parametric tests were not met for shell height growth and wet weight gain data, even after an arcsine square root transformation, we used the Kruskal-Wallis test to test for differences between treatments (electrolysis vs control). As the overall test was significant, a Dunn procedure with a Bonferroni correction was performed to determine which means were significantly different. Pearson's correlation coefficient was used to measure the correlation between shell height and wet weight for Medium and Large pearl oysters.

Shell thickness ratio was analyzed using the arcsine square root transformation. The data followed the conditions for application of parametric tests and the effect of the treatment (electrolysis or control) was tested using a one-way ANOVA.

The expression values of the six candidate genes did not meet the conditions for parametric tests. Kruskal-Wallis tests were therefore used to test for differences in gene expression between the treatments (electrolysis vs control). As the overall test was significant, a Dunn procedure with a Bonferroni correction was performed to determine which means were significantly different.

\section{Results}

\subsection{Juvenile growth: shell height and oyster weight}

Whatever the size group (Large or Medium) or type of treatment (electrolysis or control), no mortality of juveniles was observed during the nine weeks of the experiment. Pearson's correlation coefficient revealed a significant positive correlation between shell height and wet weight for Medium and Large individuals by each week $(\rho=0.622$ with $p$-value $<0.0001$ for 
Medium individuals and $\rho=0.693$ with $p$-value $<0.0001$ for Large individuals). However, we

231 decided to study these two parameters separately for both size-class group and condition.

232 Shell height growth rate was higher for Medium juveniles subjected to electrolysis in

233 comparison to the control. Shell height growth increased from $1.2 \%$ (week 1) to $7.3 \%$ (week

234 8) in electrolysis conditions and from $0.9 \%$ (week 1) to $4.9 \%$ (week 8) in control conditions

235 (Fig. 2a). The difference was only significant by the seventh week of the experiment. For the

236 Large juveniles group, the growth rate increased from $0.5 \%$ (week 1) to $6.42 \%$ (week 8)

237 under electrolysis conditions and from 0.5 to $3.6 \%$ under control conditions (Fig. 2b). The

238 difference was significant from weeks 5 to 8.

239 Wet weight gain of Medium juveniles increased from 1.9 to $11.3 \%$ and from 2.1 to

$2408.4 \%$ under electrolysis and control conditions, respectively (Fig. 3a). The difference was

241 significant by the ninth week. For Large individuals, the wet weight gain increased from 2.5

242 to $10.2 \%$ and from 1.2 to $3.7 \%$ under electrolysis and control conditions, respectively (Fig.

243 3b). The difference was significant from weeks 2 to 9.

\subsection{Shell thickness ratio}

Shell thickness ratio represents the thickness of aragonite deposited during the experiment divided by the total thickness of the shell cross section (Fig. 4). The mean shell thickness ratio and standard error (SE) varied from $24.8 \% \pm 3.1$ to $28.3 \% \pm 3.6$ for Medium juveniles and from $26.3 \% \pm 7.2$ to $28.0 \% \pm 5.3$ for Large juveniles under electrolysis and control conditions, respectively. There were no statistically significant differences between the

\section{ANOVA.}


For juvenile oysters belonging to the Medium group, all the six biomineralizationrelated targeted genes were strongly up-regulated by electrolysis in comparison to the control (without electrolysis), with expression ratios ranging from 17.02 to 90.09 for the Pif 177 and Shematrin 9 genes, respectively (Fig. 5a). Despite great variation in the expression levels of control oysters, the expression ratios of four genes were significantly higher after electrolysis treatment: Pif $177(p=0.016)$, Prismalin $14(p=0.016)$, Shematrin $9(p=0.009)$, and Aspein ( $p=0.009$ ). Similar results (but of lower amplitude) were obtained for the Large juveniles group, in which Nacrein, Shematrin 9, Prismalin 14, and Aspein were significantly upregulated by electrolysis with $p$-values of $0.017,0.008,0.001$, and 0.003 , respectively (Fig. 5b). Overall, the results revealed that MSI60 was the only gene in the panel tested that was not significantly regulated by electrolysis.

\section{Discussion}

The effect of electrolysis on the pearl oyster $P$. margaritifera biomineralization process was evaluated in this study. Measurements of the growth rate (shell height, wet weight and shell thickness ratio) as well as the levels of expression of a panel of six biomineralization-related genes were assessed in the calcifying pearl oyster.

\subsection{Electrolysis may increase some growth rate parameters in Pinctada margaritifera}

$P$. margaritifera growth rate depends on a combination of genetic and environmental factors (Pouvreau and Prasil, 2001; Mavuti et al., 2005), making it highly variable among rearing sites. In our experiment, we used individuals issued from a limited number of parents to minimize genetic influence on the results. On the one hand, P. margaritifera growth rates (shell height and wet weight) were only significantly higher for Medium individuals subjected to electrolysis compared to the control at the 7th week and the 9th week, respectively. This 
group showed higher variability than Large individuals for the shell height growth measures regardless of the treatment. This variability could have potentially masked the electrolysis effect, preventing its detection. Experiment with a greater number of oysters is necessary to test this hypothesis. On the other hand, Large juvenile shell height and wet weight growth rates were significantly higher for individuals subjected to electrolysis compared with the control from the 5th and the 2 nd week, respectively, until the end of the experiment.

Growth performance is of great interest for the reduction of bivalve mortality. Johnson and Smee (2012) found an inverse relationship between bivalve size and susceptibility to predation. Juvenile P. margaritifera pearl oysters are particularly vulnerable to predation, and the presence of predators could reduce shell growth rates (Pit and Southgate, 2003). However, we found no difference in shell thickness ratio between individuals subjected to electrical current and those in control conditions. According to Crossland (1911), shell growth of pearl oysters usually begins with a rapid increase in the shell height to reach a maximum size, which is then followed by shell thickness growth. Thus, the ratio of the shell thickness to the shell length increases with age for pearl oysters of the genus Pinctada (Hynd, 1955). As pearl oysters in our study were juveniles, they might well have invested their energy in shell length increment rather than shell thickness. Similar experiments should be repeated with older $P$. margaritifera individuals to test this hypothesis.

\subsection{Electrolysis stimulates some biomineralization-related gene expression levels in} Pinctada margaritifera 
influence of parentage, wide-ranging variations in gene expression levels were observed, mainly in Medium oysters. A high variability in gene expression has already been reported in Pinctada margaritifera (Lemer et al., 2015), both in pooled ( $\mathrm{n}=2$ with 5 individuals per pool) and individual $(\mathrm{n}=10)$ analyses, targeting genes potentially involved in the color of the nacreous layer of the pearl oyster, most of which are also involved in biomineralization of the nacreous and calcitic layers, such as Pif 177 and Shematrin 9, respectively. In the present study, the transcript levels of the Pif 177, Shematrin 9, Prismalin 14, and Aspein genes were significantly higher for the electrolysis treatment than for the control conditions in Medium individuals.

Regarding the Large individuals, the relative expression levels of Nacrein, Shematrin 9, Prismalin 14, and Aspein genes were significantly higher for the electrolysis treatment than for the control. Two of the studied genes, Pif 177 and Shematrin 9, have previously been found to be positively correlated with shell deposition rates in P. margaritifera (Joubert et al., 2014). Only MSI60 gene expression levels were not statistically different between the two treatments for either of the two size-selected groups used in our study. Interestingly, Joubert et al. (2014) found a significant negative correlation between the expression level of this gene and shell deposition rate.

Our results suggest that some biomineralization-related genes could be up-regulated by electrolysis. Biomineralization is an energetically costly process, with the production of skeletal organic matrix, which is considered to be more demanding metabolically than the crystallization of calcium carbonate (Palmer, 1983). The cost of calcification was calculated as equivalent to $75 \%$ and $410 \%$ of the energy invested in somatic growth and reproduction, respectively, for the gastropod Tegula funebralis (Palmer, 1992). In our experiment, the higher abundance of biomineralization-related transcripts could result from extra energy 
would be of interest to identify P. margaritifera genes involved in the metabolism of ATP, such as the F1- $\beta$-subunit found in P. fucata (Liu et al, 2007), in order to further quantify their expression levels in the mantle and better understand the effect of electrolysis on biomineralization processes.

\section{Conclusion}

We show that electrolysis may enhance some growth rate parameters in Pinctada margaritifera. Our findings also indicate that some biomineralization-related genes are overexpressed under electrolysis compared with control conditions. However, we found no significant differences in shell thickness ratio between the treatments for either of the two size-class groups studied. Individuals in our study were juveniles and might have invested their energy in shell length increment rather than thickness growth. Stimulating pearl oyster growth to more rapidly reach a size suitable for the graft operation would significantly help to increase the cost-effectiveness of the pearl industry. Furthermore, these first results open the way for the evaluation of electrolysis effects on: 1) selected donor oyster lines with high potential for nacre deposition as pearl oyster aquaculture takes a long time (18 to 24 months), and 2) cultured pearl quality traits, especially nacre thickness, as size remains one of the most important traits for pearl value.

\section{Acknowledgements}

This study was funded by the Agence Nationale de la Recherche (ANR, www.agence nationale-recherche.fr), as part of the POLYPERL project (ANR11-AGRO-006-01-

353 POLYPERL, www.polyperl.org). The authors are grateful to Nono Tetaura, Manaarii Sham- 
355 in this study, which was produced as part of another research project, RikiGEN, supported by

356 the Ministère des Outre Mers. We are also indebted to the Hilton Bora Bora Nui Hotel, which

357 allowed us to perform pearl oyster rearing with its electrolysis apparatus and to Helen

358 McCombie, from Brest University Translation Bureau, for helpful language improvement.

360 References

362 Belcher, AM., Wu, X.H., Christensen, R.J., Hansma, P.K., Stucky, G.D., Morse D.E., 1996.

363 Control of crystal phase switching and orientation by soluble mollusc-shell proteins. Nature $364381,56-58$.

Blay, C., Sham-Koua, M., Vonau, V., Tetumu, R., Cabral, P., Ky, C.L., 2014. Influence of nacre rate on cultured pearl grade and colour in the black lipped pearl oyster Pinctada margaritifera using farmed donor families. Aquaculture International 22 (2), 937-953.

Borell, E.M., Romatzki S.B.C., Ferse S.C.A.. 2010. Differential physiological responses of two congeneric scleractinian corals to mineral accretion and an electrical field. Coral Reefs, 29: 191-200.

Coeroli, M. and Mizuno, K, 1985. Study of different factors having an influence upon the pearl production of the black lip pearl oyster. Proceedings of the Fifth International Coral Reef Congress, Tahiti, Vol. 5, 551-556.

Cochennec-Laureau, N., Montagnani, C., Saulnier, D., Fougerouse, A., Levy, P., Lo C., 2010.

376 A histological examination of grafting success in pearl oyster Pinctada margaritifera in 
378 Crossland, C., 1911. The marginal processes of lamellibranch shells. Proc. Zool. Soc. Lond.

379 1911: 1067-1061.

380 Gervis, M.N., Sims, N.A., 1992. The Biology and Culture of Pearl Oysters (Bivalvia:

381 Pteriidae). ICLARM Studies and Reviews 21, 1-49.

382

Hilbertz, W.H., 1979. Electrodeposition of Minerals in Sea Water: Experiments and Applications. IEEE Journal on Oceanic Engineering 4, 1-19.

Hynd, J.S., 1955. A revision of Australian pearl shells, genus Pinctada. Australian Journal of Marine and Freshwater Research 6(1): 98-137.

Isowa, Y., Sarashina, I., Setiamarga, D.H., Endo, K., 2012. A comparative study of the shell matrix protein aspein in pterioid bivalves. Journal of Molecular Evolution 75, 11-18.

Johnson, K.D., Smee, D.L., 2012. Size matters for risk assessment and resource allocation in bivalves. Marine Ecology Progress Series 462, 103-110.

Joubert, C., Piquemal, D., Marie, B., Manchon, L., Pierrat, F., Zanella-Cléon, I., Cochennec-

Laureau, N., Gueguen, Y., Montagnani, C., 2010. Transcriptome and proteome analysis of

400 Joubert, C., Linard, C., Le Moullac, G., Soyez, C., Saulnier, D., Teaniniuraitemoana, V., Ky, 401 C.L., Gueguen, Y., 2014. Temperature and food influence shell growth and mantle gene 
expression of shell matrix proteins in the pearl oyster Pinctada margaritifera. PLoS ONE 9(8), e103944. doi:10.1371/journal.pone.0103944.

404

Kishore, P., Southgate, P.C, 2014. A detailed description of pearl-sac development in the black-lip pearl oyster, Pinctada margaritifera (Linnaeus 1758). Aquaculture Research 1-12.

407

Ky, C.L., Blay, C., Sham-Koua, M., Vanaa, V., Lo, C., Cabral, P. 2013. Family effect on cultured pearl quality in black-lipped pearl oyster Pinctada margaritifera and insights for genetic improvement. Aquatic Living Resources 26, 133-145.

Ky, C.L., Molinari, N., Moe, E., Pommier, S., 2014. Impact of season and grafter skill on nucleus retention and pearl oyster mortality rate in Pinctada margaritifera aquaculture. Aquaculture International 22(5), 1689-1701.

Larsen, J.B., Frischer, M.E., Rasmussen, L.J., Hansen, B.W., 2005. Single-step nested multiplex PCR to differentiate between various bivalve larvae. Marine Biology 146, 11191129.

Lemer, S., Saulnier, D., Gueguen, Y., Planes, S., 2015. Identification of genes associated with shell color in the black-lipped pearl oyster, Pinctada margaritifera. BMC Genomics 16, 568.

Le Pabic, L., Parrad, S., Sham-Koua, M., Nakasai, S., Saulnier, D., Devaux, D., Ky, C.L., (this issue). Culture site dependence on pearl size realization in Pinctada margaritifera in relation to recipient oyster growth and mantle graft biomineralization gene expression using the same donor phenotypes. 
428 Levi-Kalisman, Y., Falini, G., Addadi, L., Weiner, S., 2001. Structure of the nacreous organic matrix of a bivalve mollusk shell examined in the hydrated state using cryo-TEM. Journal of Structural Biology 135, $8-17$.

Liu, L., Xie, L., Xiong, X., Fan, W., Chen, L., Zhang, R., 2007. Cloning and characterization of an mRNA encoding F1-ATPase beta-subunit abundant in epithelial cells of mantle and gill of pearl oyster, Pinctada fucata . Tsinghua Science and Technology 12(4), 381-388.

Livak, K.J., Schmittgen, T.D., 2001. Analysis of relative gene expression data using real-time quantitative PCR and the 2(-Delta Delta C(T)) Methods 25(4), 402-408.

Mann S., 1988. Molecular recognition in biomineralization. Nature 332, 119-124.

Marie, B., Joubert, C., Tayalé, A., Zanella-Cléon, I., Belliard, C., Piquemal, D., Cochennec-

Laureau, N., Marin, F., Gueguen, Y., Montagnani, C., 2012. Different secretory repertoires control the biomineralization processes of prism and nacre deposition of the pearl oyster shell. Proceedings of the National Academy of Sciences 109(51), 20986-20991.

Mavuti, K.M, Kimani, E.N, Mukiama, T., 2005. Growth patterns of the pearl oyster Pinctada margaritifera L. in Gazi Bay, Kenya. African Journal of Marine Science 27(3), 567-575.

Miyamoto, H., Endo, H., Hashimoto, N., Limura, K., Isowa, Y., Kinoshita, S., Kotaki, T., 
Miyashita, T., Wada, H., Samata, T., Endo, K., Nagasawa, H., Asakawa, S., Watabe, S., 2013.

453 The diversity of shell matrix proteins: Genome-wide investigation of the pearl oyster, 454 Pinctada fucata. Zoological Science 30(10), 801-816.

455

Montagnani, C., Marie, B., Marin, F., Belliard, C., Riquet, F., Tayalé, A., Zanella-Cléon, I.,

Fleury, E., Gueguen, Y., Piquemal, D., 2011. Pmarg-Pearlin is a matrix protein involved in nacre framework formation in the pearl oyster Pinctada margaritifera. Chembiochem 12, $2033-2043$.

460

Palmer, A. R., 1983. Relative cost of producing skeletal organic matrix versus calcification: evidence from marine gastropods. Marine Biology 75, 287-292.

463

Palmer, A. R, 1992. Calcification in marine molluscs: how costly is it? Proceedings of the National Academy of Sciences 89, 1379-1382.

466

Piazza, B. P., Piehler, M.K., Gossman, B.P., La Peyre, M.K., La Peyre, J.F, 2009. Oyster recruitment and growth on an electrified artificial reef structure in grand isle, Louisiana. Bulletin of Marine Science 84(1), 59-66.

470

Pit, J.H. and Southgate, P.C., 2003. Fouling and predation; how do they affect growth and 472 survival of the blacklip pearl oyster, Pinctada margaritifera, during nursery culture ? Aquaculture International 11, 545-555. 
475 Pouvreau, S. and Prasil V., 2001. Growth of the black-lip pearl oyster, Pinctada

476 margaritifera, at nine culture sites of French Polynesia: synthesis of several sampling designs

477 conducted between 1994 and 1999. Aquatic Living Resources, 14, 155-163.

478 Sabater, M.G., Yap, H.T., 2002. Growth and survival of coral transplants with and without 479 electrochemical deposition of $\mathrm{CaCO}_{3}$. Journal of Experimental Marine Biology and Ecology $480 \quad 272,131-146$.

481

482 Sabater, M.G., Yap, H.T., 2004. Long-term effects of induced mineral accretion on growth,

483

484

485

486

487

488

489

490

491

492

493

494

495

496

497

498

499

survival and corallite properties of Porites cylindrica Dana. Journal of Experimental Marine Biology and Ecology 311, 355-374.

Sudo, S, Fujikawa, T, Nagakura, T, Ohkubo, T, Sakaguchi, K, Tanaka, M., Nakashima, K., 1997. Structures of mollusc shell framework proteins. Nature 387: 563-564.

Suzuki, M., Murayama, E., Inoue, H., Ozaki, N., Tohse, H., Kogure, T., Nagasawa, H., 2004. Characterization of Prismalin-14, a novel matrix protein from the prismatic layer of the Japanese pearl oyster (Pinctada fucata). Biochemical Journal 382(Pt 1), 205-213.

Suzuki, M., Saruwatari, K., Kogure, T., Yamamoto, Y., Nishimura, T., Kato, T., Nagasawa, H., 2009. An acidic matrix protein, Pif, is a key macromolecule for nacre formation. Science 325(5946), 1388-1390.

Taylor, J.J., Strack, E., 2008. Pearl production. In: Southgate, P.C., Lucas, J.S. (Eds.),The Pearl Oyster. Elsevier, pp. 273-302. 
500 Tisdell, C., Poirine, B., 2008. Economics of Pearl Farming. In: Southgate, P.C., Lucas, J.S.

501 (Eds.),The Pearl Oyster. Elsevier, pp. 473-495.

502

503

van Treeck, P., Schuhmacher, H., 1997. Initial survival of coral nubbins transplanted by a new

504 coral transplantation technology: options for reef rehabilitation. Marine Ecology Progress

505 Series 150, 287-292.

506

507 Yano, M., Nagai, K., Morimoto, K., Miyamoto, H., 2006. Shematrin: a family of glycine-rich

508 structural proteins in the shell of the pearl oyster Pinctada fucata. Comparative Biochemistry

509 and Physiology Part B: Biochemistry and Molecular Biology 144(2), 254-262.

510

511 Wane, G., 2013. Les problèmes réels de l'industrie de la perle de Tahiti, Tahiti Pacifique, mensuel d'information et d'économie, 260, 15-24. 
515 Table 1. Set of forward and reverse primers used in the gene expression analysis.

516

\begin{tabular}{|c|c|c|c|}
\hline Gene & $\begin{array}{l}\text { GenBank } \\
\text { Accession } \\
\text { Numbers }\end{array}$ & Forward primer $\left(5^{\prime}-3^{\prime}\right)$ & Reverse primer $\left(5^{\prime}-3^{\prime}\right)$ \\
\hline PIF 177 & HE610401 & AGATTGAGGGCATAGCATGG & TGAGGCCGACTTTCTTGG \\
\hline MSI60 & SRX022139* & TCAAGAGCAATGGTGCTAGG & GCAGAGCCCTTCAATAGACC \\
\hline Nacrein A1 & HQ654770 & CTCCATGCACAGACATGACC & GCCAGTAATACGGACCTTGG \\
\hline Shematrin 9 & ABO92761 & TGGTGGCGTAAGTACAGGTG & GGAAACTAAGGCACGTCCAC \\
\hline Prismalin 14 & HE610393 & CCGATACTTCCCTATCTACAATCG & CCTCCATAACCGAAAATTGG \\
\hline Aspein & SRX022139* & TGAAGGGGATAGCCATTCTTC & ACTCGGTTCGGAAACAACTG \\
\hline
\end{tabular}

$517 *$ *SRA accession number; EST library published in Joubert et al., 2010. 

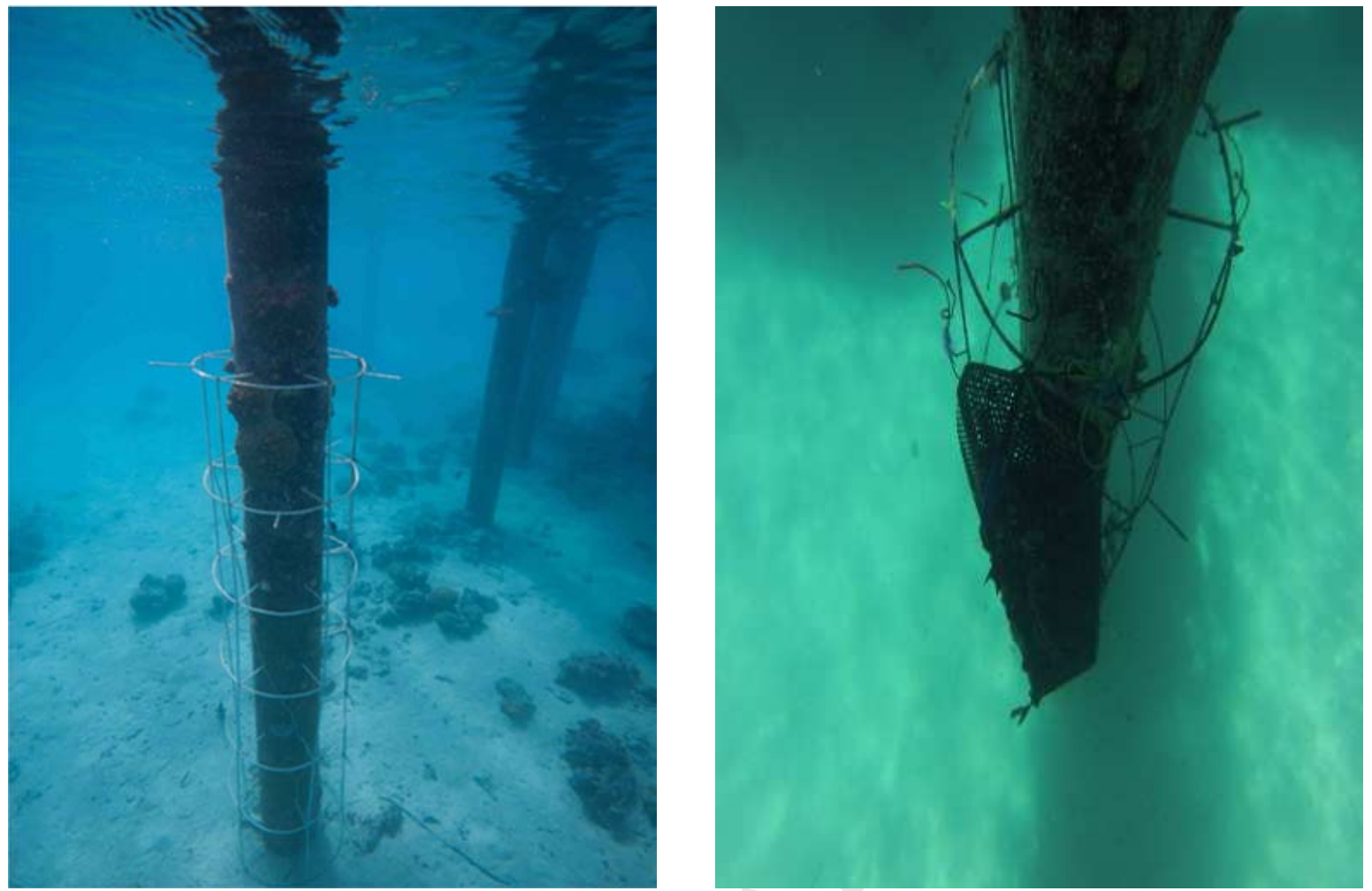

Figure 1. Photograph of the empty culture structure (left), to which an Aquapurse plastic tray was 
536

537

538

539

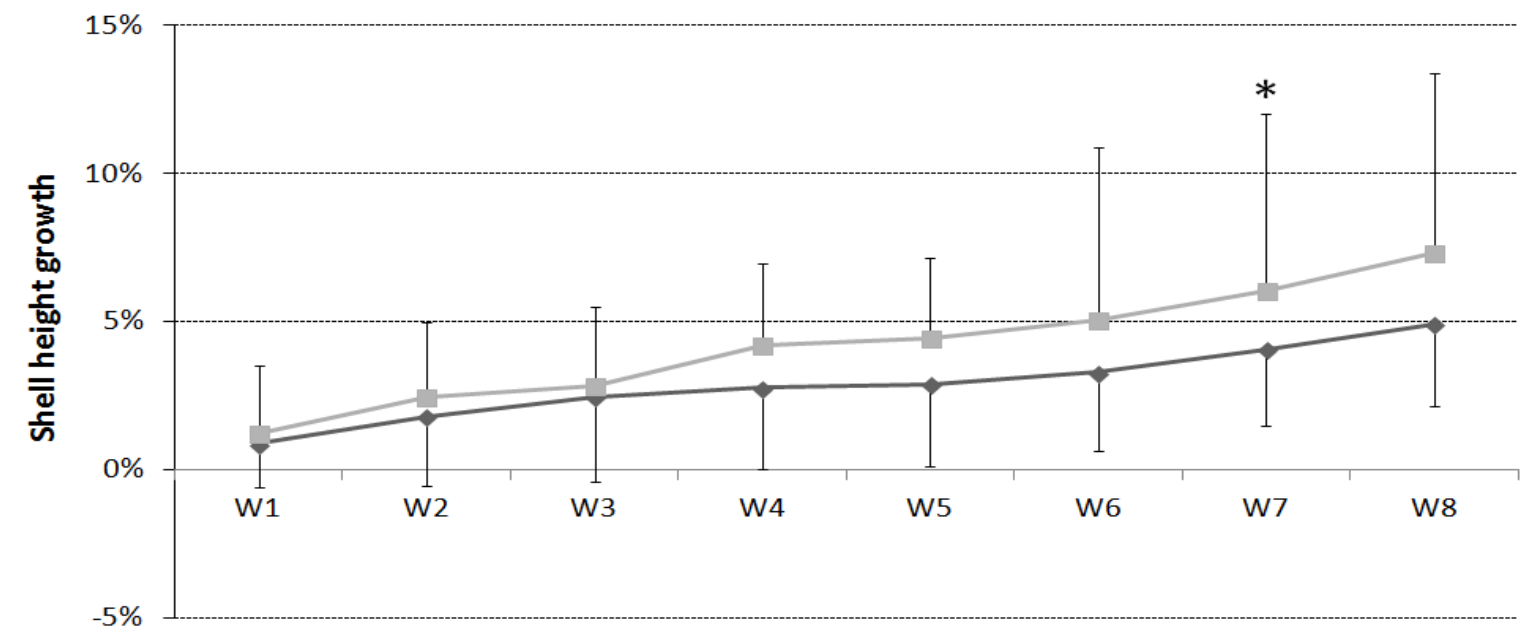

Time (weeks)

540

541

542

543

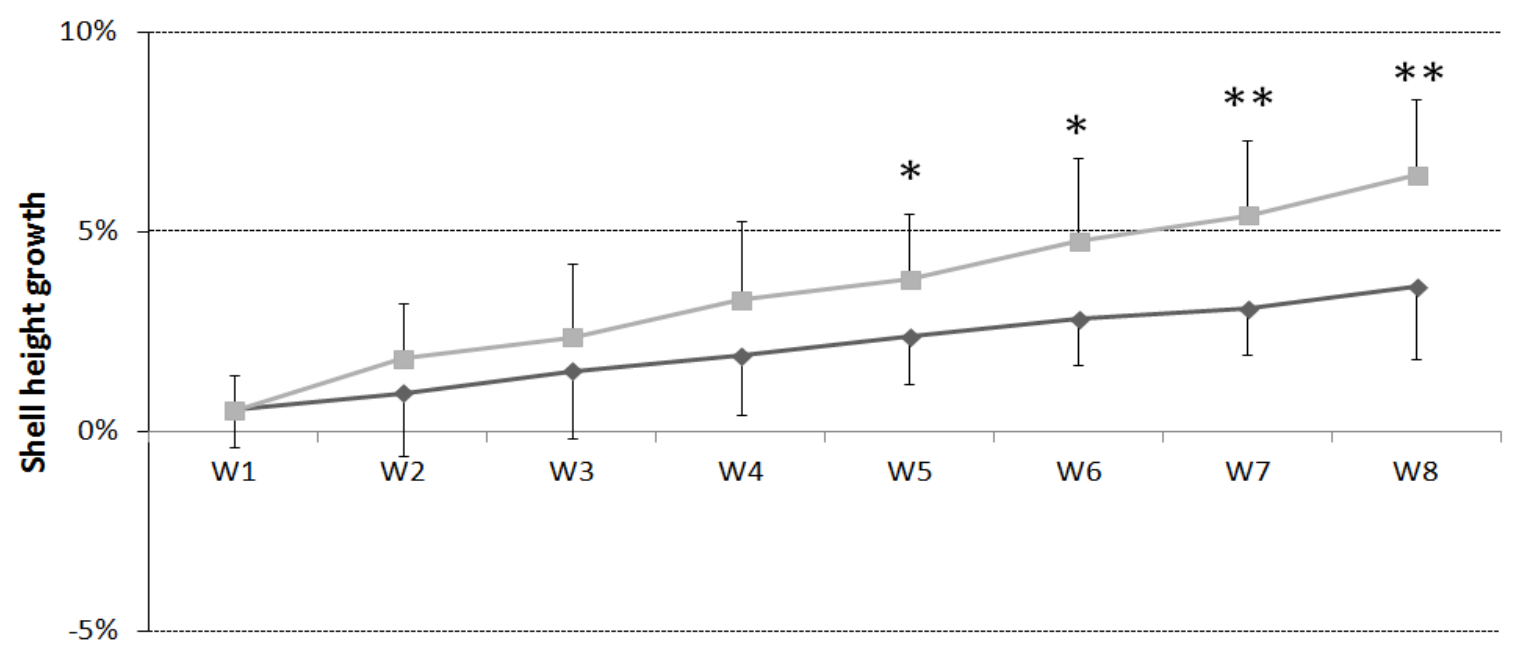

Time (weeks)

544

545

546

547

548

549 


\section{ACCEPTED MANUSCRIPT}

551 Figure 2. Average shell height growth (expressed in \%) for Medium (a) and Large (b) P. margaritifera

552 juveniles ( $\mathrm{n}=20$ per condition for Medium individuals and $\mathrm{n}=15$ for Large individuals). Shell

553 heights were measured each week in treatments with (light grey, square symbol) and without (dark

554 grey, diamond-shaped symbol) electrolysis. At the beginning of the experiment (W0), absolute

555 average shell heights were $3.71 \mathrm{~cm} \pm 0.44$ and $3.92 \mathrm{~cm} \pm 0.38$ in Medium pearl oysters in control and

556 electrolysis conditions, respectively. They were $5.05 \mathrm{~cm} \pm 0.42$ and $5.11 \mathrm{~cm} \pm 0.32$ in Large pearl

557 oysters in control and electrolysis conditions, respectively. Cumulative shell height growth was

558 calculated with the formula $\mathrm{PR}=\left(100 \times\left(\mathrm{V}_{\mathrm{W}}-\mathrm{V}_{\mathrm{w} 0}\right)\right) / \mathrm{V}_{\mathrm{w} 0}$, where $\mathrm{PR}$ is the percent change, $\mathrm{V}_{\mathrm{W}}$ the

559 present value by week "W" and $\mathrm{V}_{\mathrm{w} 0}$ the initial value by week W0. Error bars indicate standard

560 deviations; statistical analysis is based on the Kruskal-Wallis test and Dunn's test with Bonferroni

561 correction. Statistical significance is indicated by asterisks as follows: $* p<0.05$, ** $p<0.01$. Week 9

562 data (W9) are missing due to a technical problem during measurement.

563 
565

a

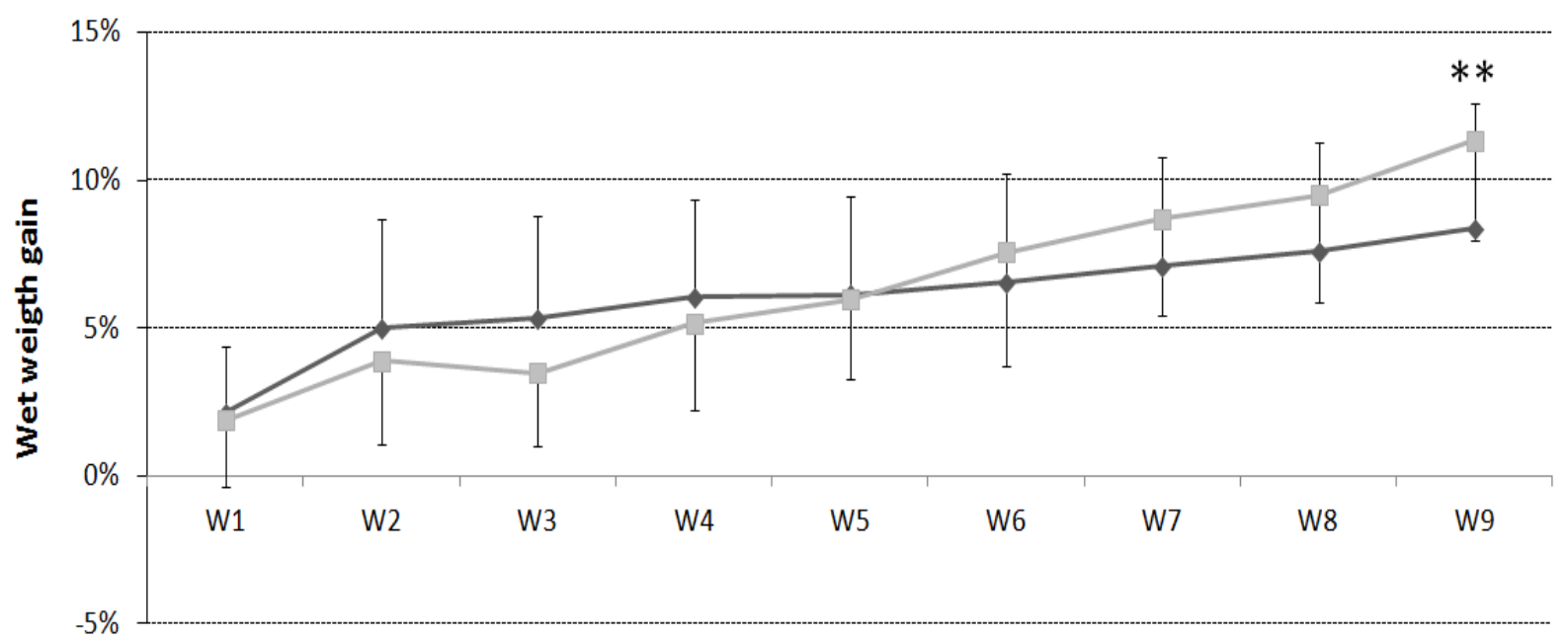

Time (weeks)

566

b

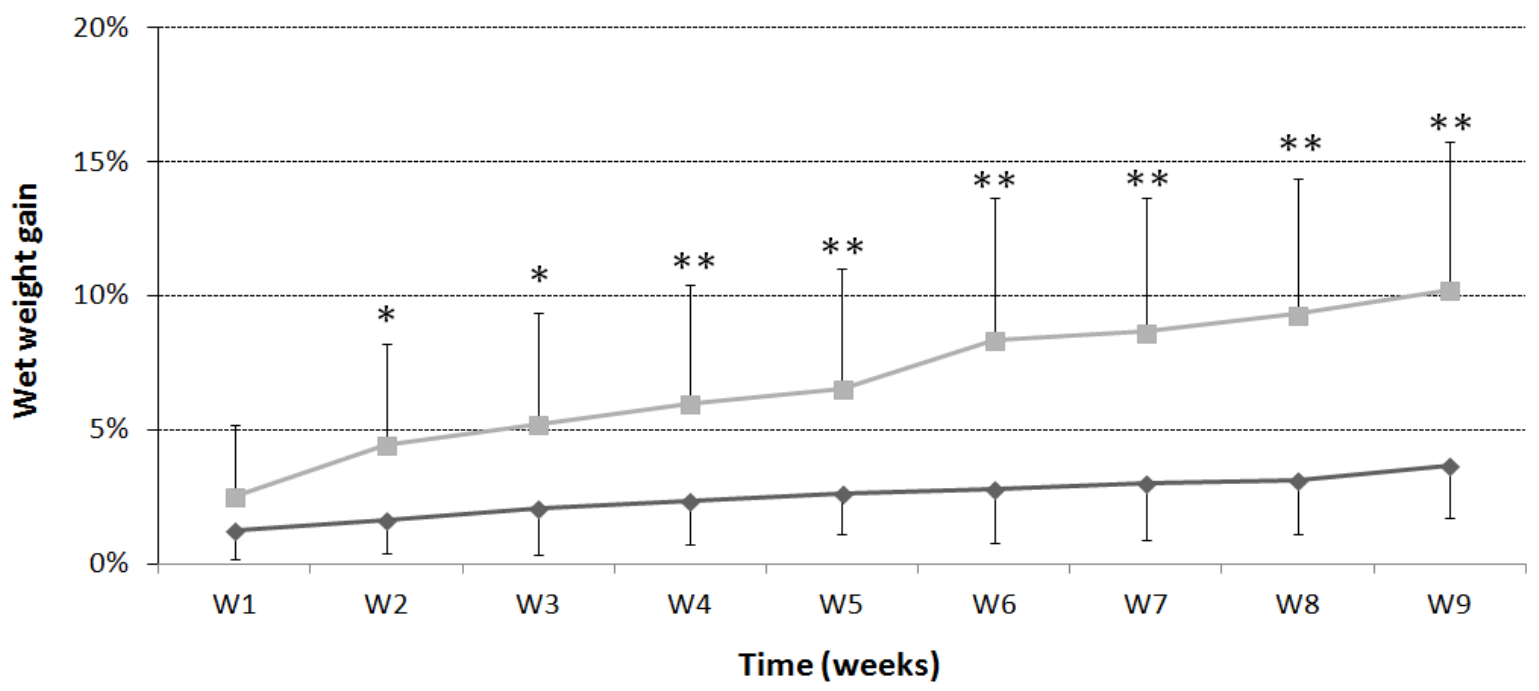




\section{ACCEPTED MANUSCRIPT}

568 Figure 3. Average wet weight gain (expressed in \%) for Medium (a) and Large (b) P. margaritifera

569 juveniles ( $n=20$ per condition for Medium individuals and $n=15$ for Large individuals). Juveniles

570 were weighed each week in treatments with (light grey, square symbol) and without (dark grey,

571 diamond-shaped symbol) electrolysis. At the beginning of the experiment (W0), absolute average

572 weights were $5.24 \mathrm{~g} \pm 1.51$ and $6.04 \mathrm{~g} \pm 1.34$ in Medium pearl oysters in control and electrolysis

573 conditions, respectively. They were $13.02 \mathrm{~g} \pm 3.68$ and $11.87 \mathrm{~g} \pm 3.15$ in Large pearl oysters in control

574 and electrolysis conditions, respectively. Cumulative wet weight gain was calculated with the formula

$575 \quad \mathrm{PR}=\left(100 \times\left(\mathrm{V}_{\mathrm{W}}-\mathrm{V}_{\mathrm{w} 0}\right)\right) / \mathrm{V}_{\mathrm{W} 0}$, where $\mathrm{PR}$ is the percent change, $\mathrm{V}_{\mathrm{W}}$ the present value by week "W" and

$576 \mathrm{~V}_{\mathrm{wo}}$ the initial value by week W0. Error bars indicate standard deviations; statistical analysis is based

577 on the Kruskal-Wallis test and Dunn's test with Bonferroni correction. Statistical significance is

578 indicated by asterisks as follows: * $p<0.05, * * p<0.01$. 


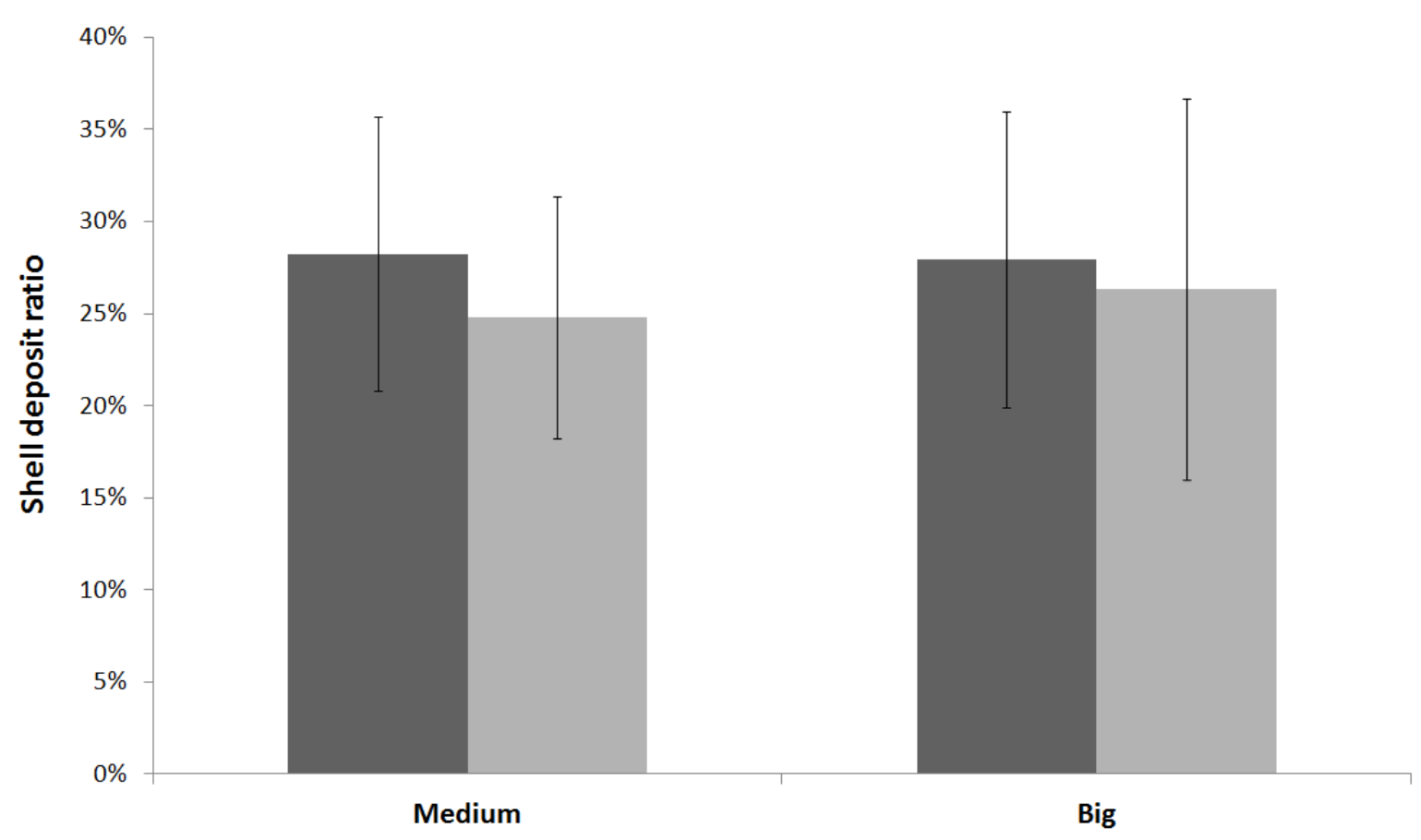

582 Figure 4. Average shell thickness ratio for Medium and Large P. margaritifera juveniles after 9 weeks

583 with (light grey) or without (dark grey) electrolysis. Shell deposit ratios were measured by dividing the

584 thickness of the deposits formed during the experiment by the total thickness of the cross section of

585 the shells and expressed as a percentage. A mean of two measurements was calculated for the cross

586 section of each individual. Error bars indicate standard deviation. No statistically significant

587 differences were found between group means using one-way ANOVA. 
590

a

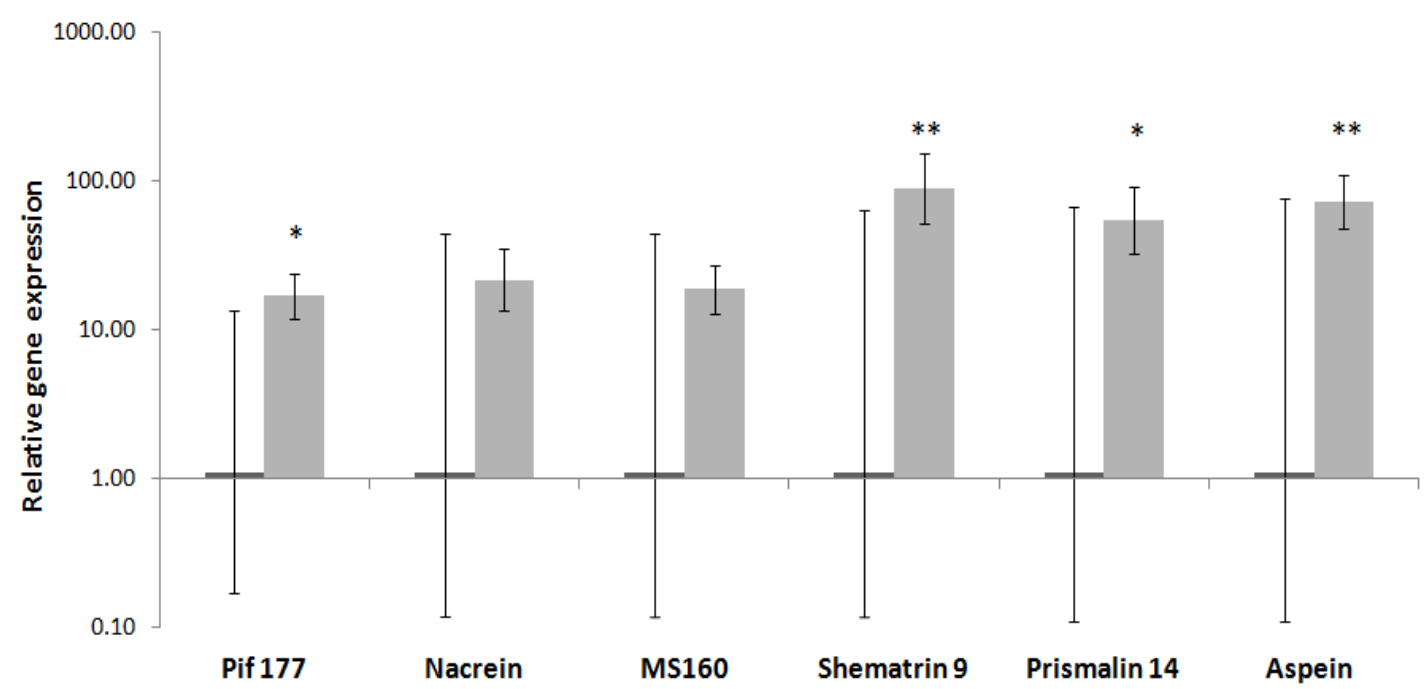

604

605

606

607

608

609

610

611

612

613

614

615

616

617

618

619

620

621

622

623

624

625

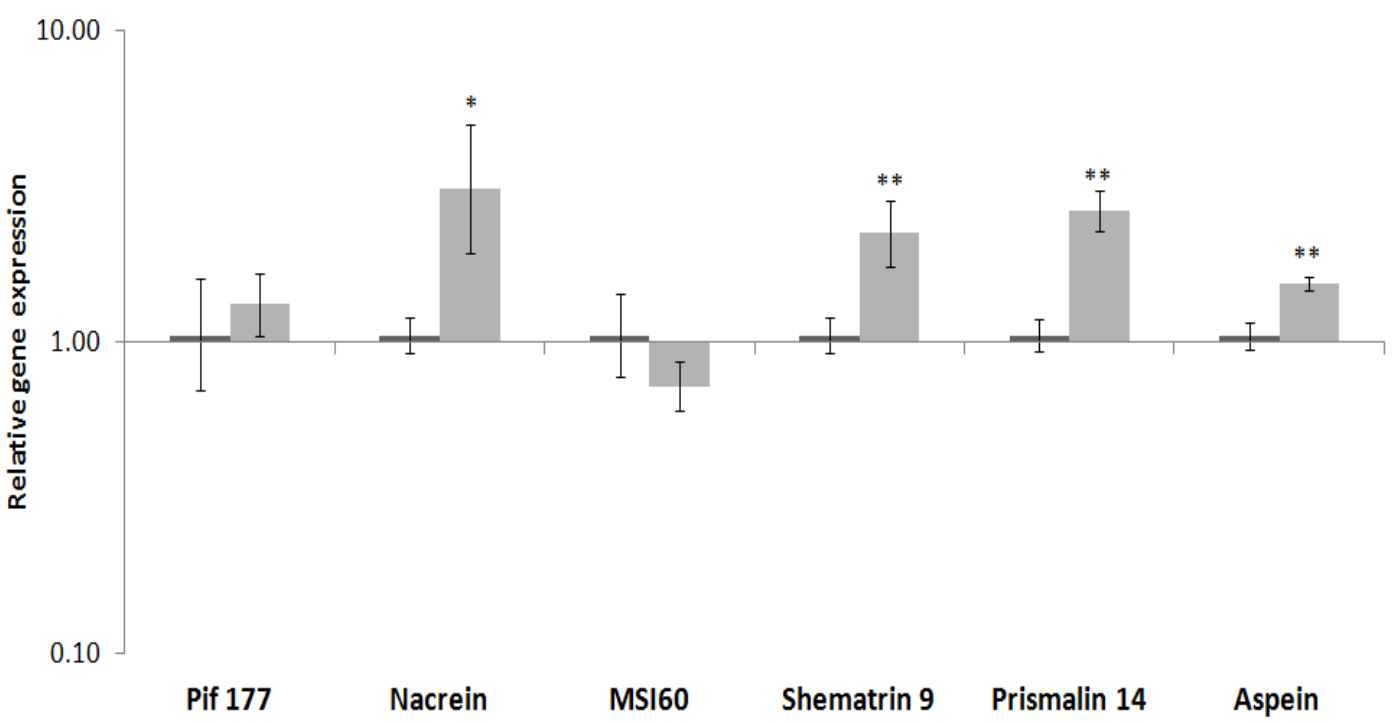


626 Figure 5. Mean relative expression of genes coding for proteins involved in the formation of the 627 nacreous layer (Pif 177, MS160), prismatic layer (Shematrin 9, Prismalin 14, Aspein) and both the 628 prismatic and the nacreous layers (Nacrein), following 9 weeks of exposure of Medium (a) and Large 629 (b) oysters to treatments with (light grey) and without (dark grey) electrolysis. The fold change means 630 were calculated from five pools of four individuals (a) and from three pools of five individuals (b) for 631 each treatment, respectively. $\mathrm{Y}$ axes are in the logarithmic scale. Error bars indicate standard 632 deviations; statistical analysis is based on Kruskal-Wallis test and Dunn's test with Bonferroni 633 correction. Statistical significance is indicated by asterisks as follows: $* p<0.05, * * p<0.01$. 